\title{
AKUNTANSI SYARIAH: SEBUAH TINJAUAN ANTARA TEORI DAN PRAKTIK
}

\begin{abstract}
Accounting theory is part of the accounting practices. A good understanding of accounting theory will encourage the development of accounting to the accounting practices. Conceptually, Islamic accounting practices present as a solution to the problems of conventional transactions that are not in accordance with Islamic values. Therefore need more explanation about the various assumptions underlying the islamic accounting practices in Indonesia. To understand and explain the islamic accounting practices applied Indonesia, it needs accounting theory approach to islamic Value.
\end{abstract}

KeyWords : Islamic Accounting theory, Accounting Practices

\section{PENDAHULUAN}

Praktik akuntansi di sebuah negara dikembangkan secara sengaja untuk mencapai tujuan sosial tertentu. Di Indonesia, perkembangan praktik akuntansi diwarnai oleh praktik akuntansi yang berdasarkan pada nilai islam, yang dikenal sebagai akuntansi syariah. Konsep syariah dalam akuntansi merupakan refleksi dari ajaran islam yang menyentuh seluruh aspek kehidupan manusia, termasuk dalam konsep ekonomi, dan akuntansi. Perkembangan akuntansi syariah merupakan bagian dari dinamika perkembangan teori akuntansi sesuai dengan kondisi sosial masyarakat indonesia yang sebagian besar adalah penduduk yang beragama islam. Konsekuensi logis dari kondisi sosial ini adalah kesediaan pemerintah untuk mengakomodir konsep akuntansi yang sesuai dengan kondisi masyarakat islam, yaitu konsep akuntansi dilihat dari sudut pandang islami.

Praktik akuntansi syariah di Indonesia telah berkembang pesat, dan mendapat respon yang positif dari masyarakat dan pemerintah. Salah satu respon dari pemerintah adalah adanya standar yang menjadi guidance bagi lembaga keuangan syariah. Di balik praktik akuntansi yang telah berkembang saat ini, baik akuntansi secara konvensional maupun syariah sebenarnya ada gagasan yang mendasari praktik-praktik tersebut berupa asumsi-asumsi dasar, konsep, penjelasan, deskripsi, dan penalaran yang membentuk bidang pengetahuan teori akuntansi (suwardjono, 2005). Oleh karena itu perlu penjelasan lebih mengenai berbagai asumsi-asumsi dasar yang mendasari praktik akuntansi syariah di Indonesia. Untuk memahami dan menjelaskan praktik akuntansi syariah yang diterapkan Indonesia, diperlukan teori akuntansi yang menggunakan pendekatan akuntansi syariah. Gagasan yang melandasi praktik akuntansi syariah sangat berbeda dengan gagasan yang mendasari praktik akuntansi konvensional, sehingga perlu penjelasan mengenai mengapa praktik akuntansi syariah di indonesia berjalan seperti sekarang ini, bagaimana perlakuan-perlakuan terhadap aset, utang, dan kewajiban secara syariah, dan adakah model-model alternatif sebagai jawaban atas masalah-masalah yang muncul dalam praktik akuntansi syariah . 


\section{TINJAUAN PUSTAKA}

\section{Teori Akuntansi}

Teori akuntansi dapat didefinisikan dari berbagai paradigma, salah satunya adalah dari cara pandang sebagai peneliti kuantitatif. Teori akuntansi jika dilihat dari sudut pandang kuantitatif, didefinisikan sebagai kumpulan construct atau konsep akuntansi dan proposisi yang menggambarkan fenomena praktik akuntansi secara sistematis melalui penentuan hubungan antar variabel untuk menjelaskan atau memprediksi fenomena praktik akuntansi di suatu negara. Pengertian tersebut sesuai dengan pendefinisian teori berdasarkan Kerlinger (Metode penelitian bisnis, Nur Indriantoro, 1999). Dari pengertian teori akuntansi yang disasarkan pada pendefinisian menurut Kerlinger, ada dua hal utama yang termasuk dalam definisi teori akuntansi, yaitu:

\section{Elemen teori akuntansi yang terdiri dari construct, konsep, definisi dan proposisi}

Elemen teori akuntansi yang menggambarkan fenomena praktik akuntansi melalui penentuan hubungan antar variabel dalam penelitian kuantitatif

\section{Konsep}

Konsep menggambarkan suatu abstraksi yang terbentuk melalui penarikan gagasan secara umum melalui pengamatan terhadap fenomena. Konsep merupakan gambaran dari realitas yang dikelompokkan dari fenomena-fenomena yang memiliki persamaan karakteristik. Tingkat abstraksi dari konsep bersifat progresif sesuai dengan tingkat kemudahan fenomena- fenomena tersebut untuk diidentifikasi. Abstraksi dalam teori akuntansi syariah seharusnya juga menggambarkan realitas fenomena praktik akuntansi dengan baik. Oleh karena itu diperlukan konsep yang baik, yang dsesuaikan dengan syariah untuk menjelaskan akuntansi dari sudut pandang syariah.

\section{Construct}

Construct merupakan konsep - konsep yang abstrak dan mempunyai makna tambahan yang diadopsi untuk keperluan ilmiah. Construct digunakan secara sistematis untuk penelitian ilmiah melalui operasionalisasi construct ke dalam konsep yang dapat diamati dan diukur menjadi variabel penelitian dan menghubungkan construct yang satu dengan construct yang lain menjadi suatu konstruksi teori. Construct diperlukan secara khusus dalam teori akuntansi untuk membangun konsep akuntansi syariah dan konstrukti teori akuntansi syariah.

\section{METODOLOGI PENELITIAN}

Artikel ini bertujuan untuk mendefinisikan kembali teori akuntansi dengan pendekatan syariah. Penelitian ini merupakan pengembangan model konseptual, dengan melakukan telaah pustaka dari berbagai macam sumber, dan berusaha menyuguhkan sebuah gagasan tentang teori akuntansi yang sesuai dengan konsep syariah. Penelitian ini merupakan studi dokumentasi, dan didasarkan pada data sekunder yang diperoleh dari jurnal, majalah, internet, serta sumber lain. 


\section{Temuan dan Pembahasan}

\section{Arti Penting Teori Akuntansi Syariah}

Teori akuntansi merupakan bagian dari praktik akuntansi. Pemahaman yang benar tentang teori akuntansi akan mendorong perkembangan akuntansi menuju praktik akuntansi yang sehat. Secara konseptual, praktik akuntansi syariah hadir sebagai solusi atas permasalahan transaksi konvensional yang tidak sesuai dengan nilainilai islami. Hal ini sesuai dengan yang disampaikan oleh Muhammad (2004) bahwa aspek-aspek akuntansi konvensional tidak dapat diterapkan pada lembaga yang menerapkan prinsip-prinsip islam, baik dari implikasi akuntansi maupun akibat ekonomi. Solusi atau jawaban dari berbagai permasalahan yang timbul dijelaskan dalam alquran yang merupakan pedoman hidup bagi umat muslim. Hal ini sangat berbeda dengan jawaban atas solusi akuntansi konvensioanal yang diperoleh melalui taktik cerdik atau penalaran yang sehat.

Baik akuntansi konvensional maupun syariah sebenarnya memiliki tujuan yang sama yaitu menuju praktik akuntansi yang baik dan sehat. Untuk menuju praktik akuntansi yang baik dan sehat, maka diperlukan teori yang baik dan sehat. Dalam konsep syariah, teori yang baik dan sehat itu diperoleh melalui al-quran sebagai pedoman hidup manusia, dan sunnah berupa segala macam hal yang dilakukan oleh nabi Muhammad SAW sebagai penerima wahyu. Akuntansi syariah sebenarnya merupakan jawaban dari masalah ekonomi saat ini dan tidak hanya diperuntukkan bagi umat muslim saja, karena karakteristik alquran adalah rahmatan lil alamin. Dari penjelasan tersebut bukan sebuah hal yang aneh, jika masyarakat non muslim pun beralih pada ekonomi islam, sehingga konsekuensi dari transaksi yang mengandung syariah maka kebijakan akuntansi yang diterapkan harus sesuai dengan standar akuntansi syariah.

Pemecahan masalah dalam praktik akuntansi konvensional dilakukan melalui taktik cerdik untuk masalah yang bersifat sederhana, dan kearifan untuk masalah yang kompleks dan memiliki pengaruh yang luas terhadap praktik akuntansi. Pemecahan masalah tersebut seringkali mengandung kepentingan praktis dan jangka pendek, yang berasal dari pembuat standar. Contoh yang seringkali muncul adalah adanya kecenderungan praktisi dan profesional yang hanya menggunakan pengalaman praktiknya dalam pemecahan masalah praktik akuntansi, dan merasa puas dengan pencapaian pengalaman praktik tersebut. Padahal kemajuan profesi akuntansi tidak hanya ditentukan oleh faktor pengalaman praktik saja, tetapi juga harus didukung dengan teori sebagai landasan dalam riset akuntansi.

Sebaliknya pemecahan masalah dalam akuntansi syariah harus bebas dari kepentingan, dan hanya ditujukan untuk tujuan yang benar sesuai dengan tujuan yang ditetapkan dalam alquran, dan berorientasi jangka panjang, tidak hanya orientasi jangka pendek saja. Dengan pendekatan teori yang benar, seharusnya orang dapat melihat masalah yang muncul dengan perspektif yang lebih luas, tidak hanya sekedar coba-coba atau trial and error. Gambling dan karim (1991) menyatakan bahwa metodologi terbaik untuk sampai pada sebuah teori akuntansi islami adalah dengan pendekatan normatif deduktif. Pendekatan normatif deduktif digunakan karena muslim harus menerapkan prisip-prinsip syariah dalam seluruh aspek kehidupan termasuk dalam kehidupan ekonomi. Pendekatan ini digunakan dalam penetapan standar akuntansi, yang mencakup bagaimana memahami tujuan laporan keuangan, rumus-rumus akuntansi dan definisi konsep prinsip-prinsip syariah. Dengan pendekatan deduktif, prinisp-prinsip teoritis akuntansi secara logis diperoleh melalui deduksi 
berbagai asumsi dari aksioma atau prinisp-prinsip awalnya (Whittington, 1986 dalam Majalah akuntan Indonesia, edisi 2, hal. 9). Dengan Pendekatan ini, maka prinsip atau aturan yang diperoleh akan sesuai dengan nilai-nilai islam.

Salah satu hal yang mendorong munculnya akuntansi syariah adalah adanya kajian ulang tentang penggunaan syariah sebagai petunjuk dalam pengembangan teori akuntansi ( Muhammad, 2004). Oleh karena itu, dalam mengembangkan teori akuntansi sudah seharusnya didasari oleh syariah atau sesuai dengan nilai- nilai islam. Teori akuntansi yang dibangun untuk memahami praktik akuntansi syariah tidak boleh bertentanngan dengan prinsip-prinsip syariah.

\section{Perkembangan Akuntansi Syariah}

Perkembangan akuntansi dipengaruhi oleh berbagai faktor, diantaranya adalah faktor sistem ideologi dan ekonomi suatu negara. Perkembangan ideologi dan ekonomi suatu negara akan berpengaruh terhadap perkembangan akuntansi di sebuah negara. Di Indonesia, perkembangan akuntansi dari masa ke masa dipengaruhi oleh adanya perkembangan idiologi agama islam, yang kemudian mendorong perkembangan ekonomi islam sebagai bentuk refleksi idiologi islam tersebut. Oleh karena itu perkembangan akuntansi sangat dipengaruhi oleh perkembangan ekonomi islam, sehingga muncullah akuntansi syariah. Faktor yang mendorong adanya kebutuhan akan akuntansi syariah adalah munculnya lembaga keuangan islam, sistem perbankan syariah, adanya skandal perusahaan skala internasional, dan juga munculnya kesadaran para akuntan untuk bertindak jujur, adil dan tidak melanggar ketentuan syariah islam.

Faktor pertama merupakan faktor besar yang mendorong bangkitnya akuntansi syariah, adalah perkembangan lembaga keuangan islam yang begitu cepat. Cepatnya perkembangan lembaga tersebut dibarengi dengan adanya tantangan yang dihadapi oleh sistem keuangan islam, termasuk bagaimana perlakuan akuntansi terhadap lembaga keuangan syariah. Tantangan yang dihadapi oleh ekonomi islam, khususnya lembaga keuangan islam adalah pada aspek teoritis, operasional, dan implementasi. Menurut Sukardi, 2009 aspek teoritis yang dihadapi oleh lembaga keuangan syariah adalah diperlukanya pengembangan prinsip, filosofi dan fungsi sistem keuangan atas dasar pembagian keuntungan dan kerugian. Pada tataran operasional, diperlukan perhatian terhadap inovasi, intermediasi, disiplin, dan pengendalian resiko, sedang pada tahap implementasi diperlukan aplikasi sistem yang disesuaikan dengan regulasi dan kondisi masyarakat saat ini.

\section{Akuntansi pada awal munculnya islam}

Akuntansi syariah telah lahir sejak dulu. Akuntansi dalam islam bukanlah seni dan ilmu yang baru. Pada awal munculnya islam akuntansi telah dikenal, salah satu dengan adanya "Baitul mal”yang merupakan lembaga yang berfungsi sebagai bendahara negara dan menjamin kesejahteraan sosial. Pengenalan akuntansi pada masa itu adalah dikenalnya "kitabat al amwal " atau pencatatan uang oleh masyarakat. Penggunaan istilah akuntansi juga telah digunakan oleh peneliti muslim jauh sebelum Luca pacioli mengenalkan double entry pada tahun 1949. Salah satu manuskrip yang berisi tentang akuntansi dan sistem akuntansi yang digunakan di negara islam adalah manuskrip yang berjudul "Risalah Falakiyah Kitab As Siyaqat" yang dihasilkan oleh 
Abdullah bin Muhammad bin Kayah Al Mazindarani pada tahun 1363 M.

\section{Era baru Kebangkitan Akuntansi Syariah}

Bangkitnya akuntansi syariah di Indonesia, dipicu oleh berbagai hal, yaitu adanya skandal akuntansi di perusahaan-perusahaan besar, seperti wordlcom, dan adanya kesadaran dari para akuntan untuk bekerja lebih jujur, adil dan tidak bertentangan dengan ajaran al quran dan al hadis (Majalah akuntan Indonesia edisi 2, hal.12). Beberapa isu lain yang ikut mendorong perkembangan terhadap kajian akuntansi syariah adalah adanya harmonisasi standar akuntansi internasional di negara -negara islam, usulan pemformatan laporan badan usaha islami, dan kajian ulang filsafat tentang konstruksi etika dalam pengetahuan akuntansi serta penggunaan syariah sebagai petunjuk dalam pengembangan teoari akuntansi syariah.

\section{Pengertian Akuntansi Syariah}

Hal utama yang berkaitan dengan akuntansi adalah pencatatan transaksi keuangan, pengakuan, penilaian, dan pengungkapan dalam laporan keuangan. Akuntansi syariah merupakan ilmu sosial Profetik, semua aturan yang berkaitan dengan akuntansi syariah didapatkan secara normatif dari Perintah yang ada dalam Al quran yang digunakan sebagai arah praktik akuntansi. Arah praktik akuntansi tersebut tentu saja akan sesuai dengan syariah. Dalam akuntansi syariah, pencatatan transaksi akuntansi dikaitkan dengan semangat islam, sesuai dengan surat Al Baqarah 282 (Fajarwati dan Sambodo, 2010). Fajarwati dan Sambodo menyatakan bahwa pencatatan transaksi keuangan yang disesuaikan dengan semangat islam adalah pencatatan transaksi yang dilakukan oleh petugas pencatat transaksi yang terbebas dari efek negatif transaksi keuangan. Sesuai dengan surat albaqarah 282, akuntansi dalam islam memiliki konsep keadilan, kebenaran, dan pertanggungjawaban (Angga dini Sri Dewi, 2010). Konsep keadilan dalam konteks akuntansi mengandung dua pengertian, yaitu yang berkaitan dengan praktik moral dan yang bersifat fundamental yang berpijak pada nilai niali syariah. Seharusnya, penyusunan laporan keuangan harus dilakukan dengan adil untuk memenuhi kebutuhan semua pihak yang berkepentingan, bukan hanya untuk memenuhi kepentingan pihak tertentu. Informasi akuntansi yang disusun hanya untuk kepentingan pihak tertentu yang cenderung tidak adil akan menyesatkan masyarakat. Konsep kebenaran ini diperoleh dari penjelasan bahwa dalam surat Al Baqarah 282 Allah memerintahkan untuk melakukan penulisan secara benar atas setiap transaksi selama melakukan kegiatan muamalah. Penerapan konsep pertanggungjawaban dalam akuntansi syariah adalah penyusunan laporan keuangan yang dilakukan oleh pelaku bisnis atau individu yang terlibat dalam praktik bisnis sebagai bentuk pertanggungjawaban atas amanah kepada pihak-pihak yang terkait.

Menurut Raharjo Kharis, dalam konsep akuntansi syariah, akuntansi memiliki dua arah kekuatan yang dapat dibentuk oleh lingkungan dan juga dapat mempengaruhi lingkungan. Akuntansi dapat mempengaruhi lingkungan, sehingga akuntansi syariah akan mempengaruhi para pelaku ekonomi termasuk pelaku transaksi kepada perilaku yang lebih etis, karena akuntansi syariah didasarkan pada prinsip islam yang menerapkan sikap etis termasuk dalam perilaku ekonomi. Informasi akuntansi memiliki kekuatan untuk mempengaruhi pikiran, tindakan, bahkan sampai pada pengambilan keputusan dalam bisnis. Hal ini akan mendorong terbentuknya 
bisnis yang lebih baik.

\section{Prinsip Akuntansi Syariah}

Teori akuntansi syariah bersifat manusiawi. Perintah normatif yang ada dalam alquran yang berkaitan dengan akuntansi sangat pro manusia, sesuai dengan fitah manusia dan dapat dipraktekkkan oleh manusia dengan segala potensi yang Allah berikan kepada manusia. Allah memberikan tiga potensi sebagai modal dasar manusia, yaitu potensi ruhyah (jiwa), fikriah (pikiran), dan jasadiah. Dengan ketiga potensi tersebut manusia dapat mempraktekkan akuntansi syariah dengan mudah. Dengan kekuatan ruhiyah yang tinggi, yang diperoleh manusia dari kedekatannya dengan Allah sebagai pencipta, manusia akan memiliki dorongan kekuatan untuk melakukan praktik akuntansi sesuai dengan apa yang diperintahkan oleh Allah, dzat yang menciptakan manusia. Kekuatan ini merupakan kekuatan utama yang mampu mendorong seseorang agar bertindak sesuai dengan syariah, termasuk dalam melakukan praktik akuntansi. Seseorang yang tidak memiliki kedekatan dengan penciptanya, atau kekuatan ruhnyahnya rendah, akan lebih mudah berbelok, dan melakukan praktik akuntansi yang tidak sehat, yaitu praktik akuntansi yang tidak sesuai dengan syariah. Dia akan melanggar aturan normatif yang ada dalam alquran. Potensi fikriah akan mempermudah manusia dalam melakukan praktik akuntansi, karena dengan potensi ini, manusia dapat membedakana mana yang benar dan mana yang salah, dan manusia dapat berfikir dengan akal yang Allah berikan. Potensi yang tidak kalah penting adalah potensi jasadiah yang akan mempermudah manusia melakukan setiap aktivitas dalam kehidupan, tanpa jasadiah yang sehat manusia tidak dapat melakukan transaksi.

Teori akuntansi syarah dapat memberikan prubahan dan perbaikan terhadap teori dan praktik akuntansi yang ada saat ini. Teori akuntansi syariah dapat mengubah cara pandang manusia dari cara pandang yang parsial menuju cara pandang yang luas, karena akntansi syariah menggunakan world view islam, secara holistik.

Teori akuntansi syariah dapat melintas batas disiplin ilmu, dengan mengadopsi disiplin ilmu lain (seperti sosiologi, psikologi) dan juga mencakup aspek materi dan non materi (mental dan spiritual)

\section{Tujuan Akuntansi Syariah}

Salah satu rancang bangun ekonomi islam adalah nubuwwah, yaitu Allah mengutus Nabi Muhammad Saw, sebagai rasulullah yang diutus menyempurnakan akhlaq manusia, dan sebagai rahmatan lil alamin. Konsep Nubuwwah memberikan pemahaman bahwa ketika seseorang ingin mencapai keselamatan dunia akhirat, maka segala aktivitas yang dilakukan harus sesuai dengan yang dicontohkan oleh Nabi Muhammad, termasuk dalam kegiatan atau aktivitas ekonomi. Oleh karena itu tujuan akuntansi syariah yang merupakan sub sistem dari ekonomi islam, adalah merealisasikan konsekeunsi dari konsep tauhid sampai pada kecintaan seseorang pada Allah swt, dengan melaksanakan akuntabilitas atas setiap transaksi dan kejadian ekonomi, dan proses produksi dalam organisasi (Mulawarman, 2007). Tujuan akuntansi syariah:

Membantu mencapai keadilan sosio ekonomi (Al Falah)

Mengenal sepenuhnya kewajiban kepada Tuhan, masyarakat, individu dengan pihak yang terkait dalam 
aktivitas ekonomi (akuntan, auditor, manajer, pemilik, pemerintah) sebagai sebuah bentuk ibadah.

Memahami setiap aktivitas yang berkaitan dengan aktivitas ekonomi sebagai sebuah bentuk ibadah adalah suatu hal yang cukup sulit bagi masyarakat islam, karena paradigma yang diajarkan oleh ekonomi kapitalis bahwa setiap aktivitas ekonomi yang dilakukan dengan auditor, akuntan atau pihak lainya adalah transaksioonal dan mengandung nilai uang

\section{Teori Akuntansi Syariah}

Berbeda dengan pendekatan kuantitatif, dalam membangun konstruksi teori akuntansi islam, penarikan gagasan ke dalam sebuah konsep tidak dilakukan melalui pengamatan terhadap fenomena yang memiliki persamaan karakteristik. Kumpulan konsep yang membentuk teori akuntansi islam diperoleh melalui penarikan gagasan yang di dasarkan pada Al quran dan Hadis. Oleh karena itu, teori akuntansi islam dapat didefinisikan sebagai kumpulan konsep akuntansi yang berasal dari nilai- nilai yang tetdapat dalam Al Quran dan Hadist, yang digunakan untuk menjelaskan dan mengembangkan praktik akuntansi.

\section{Posisi dan Peran Teori Akuntansi Syariah}

Teori akuntansi sangat penting bagi perkembangan dunia pendidikan akuntansi, terutama dalam penelitian kuantitatif. Teori akuntansi digunakan untuk menjelaskan mengapa praktik akuntansi dapat terjadi. Oleh karena itu teori akuntansi syariah diperlukan untuk menjelaskan praktik akuntansi syariah yang berkembang pada lembaga keuangan syariah. Posisi teori akuntansi islam dijelaskan dalam bagan konsep akuntansi syariah. Konstruksi akuntansi syariah lahir dari nilai-nilai budaya masyarakat islam, sebagai wujud dari penerapan nilai Tauhid yang direalisasikan dan dipraktekkan pada seluruh aspek kehidupan, termasuk kehidupan sosial ekonomi. Akuntansi syariah merupakan konstruksi sosial masyarakat islam dalam penerapan ekonomi islam, dan merupakan sub sistem dari sistem ekonomi islam. Untuk mendukung praktik akutansi syariah yang sehat maka diperlukan teori akuntansi islam yang sehat.

\section{Tujuan Teori Akuntansi Syariah}

Teori akuntansi digunakan untuk menjelaskan dan memprediksi fenomena akuntansi pada sebuah negara. Teori akuntansi syariah diperlukan dalam sistem akuntansi untuk memisahkan antara transaksi yang halal dan haram. Kebutuhan terhadap sistem akuntansi yang seperti itu memunculkan berbagai penelitian dan studi tentang bagaimana seharusnya akuntansi diterapkan sesuai dengan syariah, sehingga tidak bertentangan dengan prinsip ekonomi islam. Sistem akuntansi syariah diterapkan sebagai bagian dari ekonomi islam, karena akuntansi syariah mampu memilah antara transaksi yang halal dan haram (Firman, 2010). Pada umumnya, ekonomi syariah, dan bisnis yang berbasis syariah memiliki ciri unik intelgensi spiritual atau yang disebut sebagai ukhuwah di dalam islam. Ciri unik ini dapat dilihat dari hubungan tolong menolong dan kepercayaan. Ciri unik tersebut teraplikasikan melalui struktur pembiayaan yang bebas agunan dan bebas riba, serta bagi hasil dalam sistem distribusi atas manfaat dari penbiayaan tersebut. 


\section{Prinsip Umum Akuntansi Syariah}

Prinsip dasar universal yang melekat dalam akuntansi syariah adalah nilai pertanggungjawaban, keadilan, dan kebenaran (Dewi, Sri, 2012). Sesuai dengan surat AI Baqarah ayat 286, bahwa setiap transaksi harus dicatat secara benar. Konsep pertanggungjawaban berkaitan dengan konsep amanah dalam setiap aktivitas manusia. Implikasi dari konsep tersebut dalam akuntansi adalah setiap orang yang terlibat dalam praktik bisnis harus melakukan pertanggungjawaban atas tindakan yang dilakukan. Bentuk pertanggungjawaban tertulis atas tindakan tersebut dalam akuntansi adalah laporan keuangan.

\section{KESIMPULAN DAN SARAN}

Teori akuntansi syariah merupakan bagian dari praktik akuntansi syariah. Teori akuntansi syariah diperlukan sebagai landasan dalam pengembangan praktik akuntansi syariah. Pemahaman yang benar tentang teori akuntansi syariah akan mendorong perkembangan akuntansi menuju praktik akuntansi yang sesuai dengan prinsip-prinsip syariah. Praktik akuntansi syariah hadir sebagai jawaban atas permasalahan transaksi konvensional yang tidak sesuai dengan nilai-nilai syariah. Teori akuntansi syariah diperlukan untuk menjelaskan berbagai asumsi dasar yang mendasari praktik akuntansi syariah di Indonesia dan menjelaskan praktik akuntansi yang sudah berjalan dan landasan dalam pengembangan akuntansi syariah pada masa akan datang.

Jurnal Akuntansi Indonesia 


\section{Daftar Pustaka}

Himawati, S. (n.d.). Praktik Akuntansi dan perkembangan Akuntansi Syariah di Indonesia. Irwadi, M. (2010). Akuntansi Syariah di Indonesia : Sebuah tinjuan Literatur. Jurnal Ocpus.

Kariyoto. (2013). Akuntansi dalam Perspektif Syariah Islam. Jurnal JIBEKA.

Kariyoto. (2014). Akuntansi syariah dalam perspektif Teori dan Implementasinya. Jurnal JIBEKA Volume 8 No. 2 Agustus, 19 - 26.

Keuangan, O. J. (2016). Booklet Perbankan Indonesia .

Keuangan, O. j. (2016). Roadmap Perbankan Syariah Indonesia 2015-2019.

Masulah. (2013). Strategi Pengembangan Perbankan Syariah di Indonesia.

MS, A. M. (2015). Keterlekatan Sosial Inovasi Produk Bank Syariah di Indonesia. Jurnal Hukum Islam.

Muhammad. (n.d.). Teori Penilaian dalam Akuntansi Syariah.

Mulawarman, A. D. (2007). Rekonstruksi Teknologi Integralistik Akuntansi Syariah (Syaria Value Added Statement). Jurnal Akuntansi dan Keuangan Indonesia, 1-24.

Muzahid, M. (n.d.). Kerangka Konseptual Akuntansi Konvensional dan Akuntansi Syariah.

Raharjo, K. (n.d.). Filosofi Akuntansi Syariah Dalam Praktek Akuntansi Lembaga Keuangan Islam.

Rifai, H. A. (2009). Identifikasi faktor Penentu Keputusan Konsumen Dalam memilih jasa Perbankan. 


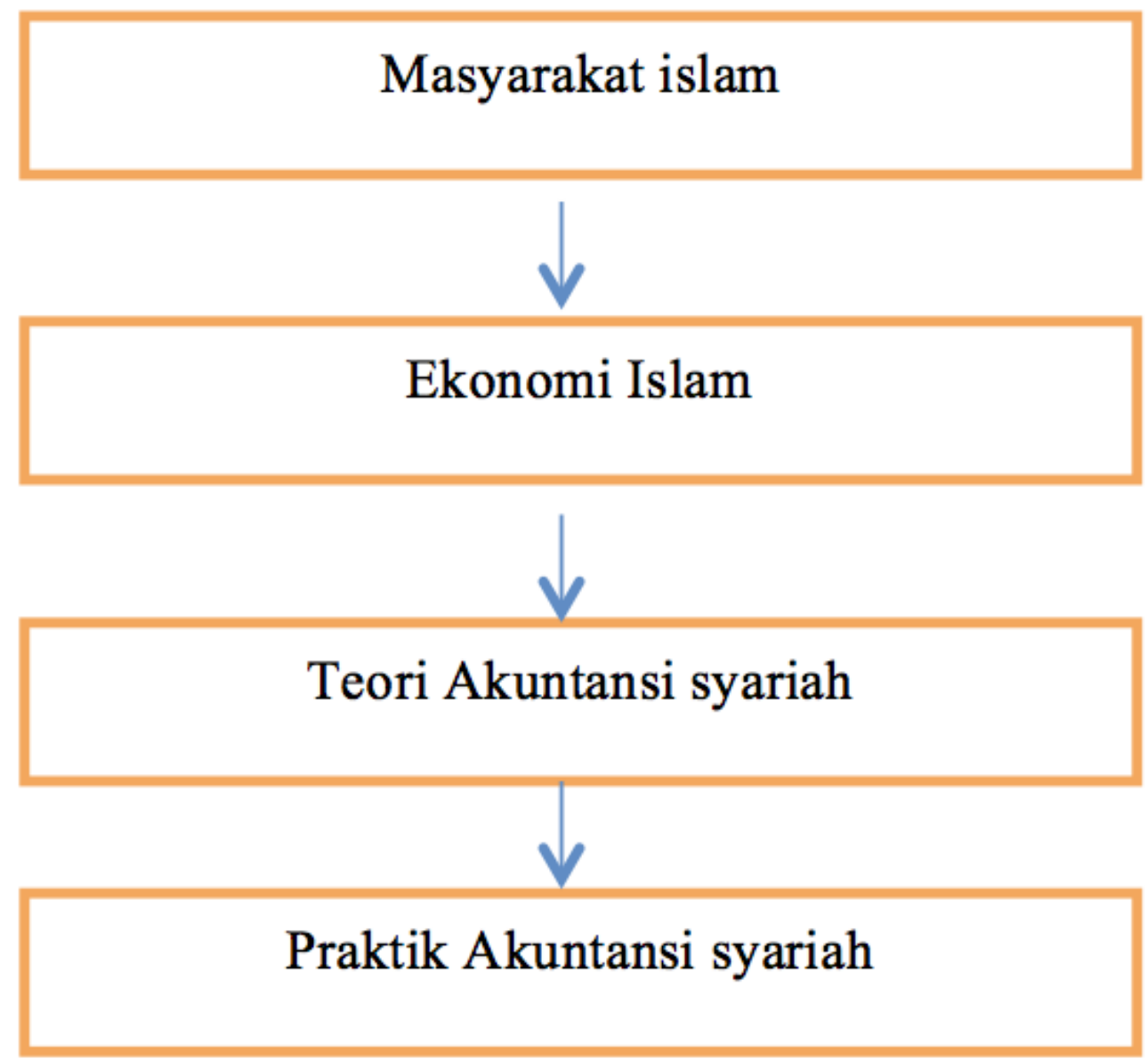

Gambar 1.1

Konsep Akuntansi Syariah

Jurnal Akuntansi Indonesia 